\title{
The effect of mixed bacterial inoculant on the microbial population and aerobic stability of lucerne and maize balage
}

\author{
R. Stoškus ${ }^{1,3}$, J. Jatkauskas ${ }^{1}$, V. Vrotniakienė $\dot{e}^{1}$ and V. Juozaitiené ${ }^{2}$ \\ Lithuanian University of Health Sciences \\ ${ }^{1}$ Institute of Animal Science, R. Zebenkos 12, LT-82317 Baisogala, Radviliskis distr., Lithuania \\ ${ }^{2}$ Faculty of Animal Husbandry Technology, Department of Animal Breeding and Nutrition, Tilzes 18, LT-47181 Kaunas, Lithuania
}

KEY WORDS: aerobic treatment, fermentation, inoculation, silage

Received: 21 February 2019

Revised: 4 September 2019

Accepted: 27 November 2019

${ }^{3}$ Corresponding author:

e-mail: robisbiz@yahoo.com

\begin{abstract}
Two forages, maize (Zea mays) and lucerne (Medicago sativa), having opposite fermentability coefficient, were ensiled in big bales for 120 days without and with application of a dual purpose bacterial inoculant containing Lactococcus lactis and Lactobacillus buchneri at $1.5 \times 10^{5} \mathrm{cfu} / \mathrm{g}$ of fresh forage. The experiments were performed using the random sampling method, where each big bale was an experimental unit. The combination of each raw material and the inoculant was replicated ten times. Inoculated maize and lucerne silages had greater level of lactic acid $(P<0.01)$ and acetic acid $(P<0.01)$ as well as reduced $\mathrm{pH}$ value $(P<0.01)$ than not inoculated ones. Application of bacterial inoculant decreased yeast $(P<0.01)$ and mould $(P<0.01)$ counts and increased lactic acid bacteria count $(P<0.01)$. Inoculant had a positive effect on aerobic stability by delaying aerobic deterioration time. The inoculation of maize and lucerne was effective at improving the fermentation aerobic stability and decreasing yeast and mould growth.
\end{abstract}

\section{Introduction}

Silage is one of the main feed sources for ruminants and is an important source of protein, nutrient, energy and fibre (Queiroz et al., 2018). It is known that the control of the silage prouction can be the most important factor determining silage fermentation, but even under controlled conditions, this process can be large and difficult to explain (Mogodiniyai Kasmaei et al., 2013). Therefore, it is necessary to pay more attention to the quality and safety issues, as the feeding of poor quality silages reduces animal productivity and endangers animal and human health (Juškienè et al., 2014).

In farms one of the major problems is aerobic spoilage of silage by yeast and other aerobic bacteria during the feeding phase. Aerobic instability of silage can adversely affect its hygienic quality by affecting the growth of moulds and the mycotoxin forming potential, which may pose a risk to humans by possible transmission of pathogens and mycotoxins to animal products such as milk. In addition, a high ambient temperature can accelerate the number of aerobic microorganisms that further accelerate the process of silage deterioration (Ogunade et al., 2016; Auerbach and Nadeau, 2018; Borreani et al., 2018). Therefore, the objectives of this study were to compare fermentation characteristics, microbial population and aerobic stability of whole crop maize and lucerne ensiled in big bales with or without a mixed lactic acid bacteria inoculant containing Lactococcus lactis and Lactobacillus buchneri. 


\section{Material and methods}

Field experiments were performed in 2016-2018 at the Institute of Animal Science of Lithuanian University of Health Sciences on the basis of the internationally acknowledged German Agricultural Society (Deutsche Landwirtschafts-Gesellschaft) guidelines (DLG, 2000) for testing silage additives and for assessment of the safety and efficacy of silage additives, on a request from the commission under Article 7 (5) of Regulation (EC) No 1831/2003 (EFSAQ-2004-088; EFSA 2006) adopted on 20 April 2006.

A lucerne (Medicago sativa) crop from one field as a difficult to ensile forage (with $32.8 \%$ dry matter (DM) and $1.64 \%$ soluble carbohydrate on a fresh matter (FM) basis) and whole crop maize as a moderately easy to ensile forage (with $33.7 \% \mathrm{DM}$ and $2.5 \%$ soluble carbohydrate on a FM basis) were used in the experiment.

\section{Experimental design}

The experiment was performed using the randomized complete block design, in which each big bale was an experimental unit. The combination of each ensiled material and the inoculant was replicated ten times: 5 replications for determination of fermentation parameters and microbiological composition and 5 replications for aerobic stability test. Big bales of lucerne and maize silages were prepared without inoculants (control - CL and CM, respectively) or with a blend of lactic acid bacteria containing Lactococcus lactis and Lactobacillus buchneri (IL and IM, respectively). The experimental design is shown in Table 1. up and baled into cylindrical bales $(120 \mathrm{~cm}$ height $\times 120 \mathrm{~cm}$ width) with baler CLASS $350 \mathrm{RC}$ (Class Group GmbH, Harsewinkel, Germany) and wrapped with a Elko-1410 (Ab El-Ho Oy, Pännäinen, Finland) wrapper using six layers of white stretch film (width $-750 \mathrm{~mm}$, thickness $-0.025 \mathrm{~mm}$ ). For big bales forage was not chopped.

Whole crop maize (Zea mays L.) at early dough stage $(33.7 \% \mathrm{DM})$ was harvested and chopped to about 1-cm length using John Deere 7550 (John Deere Europe $\mathrm{GmbH}$, Mannheim, Germany) forage harvester on $18^{\text {th }}$ October 2016 and was delivered to place for big bales making. Baling of chopped whole crop maize was performed using equipment Göweil LT-Master (Göweil Maschinenbau GmbH, Kirchschlag bei Linz, Austria). Cylindrical bales (120 cm height $\times 120 \mathrm{~cm}$ width) were wrapped with six layers of white film (width $-750 \mathrm{~mm}$, thickness $-0.025 \mathrm{~mm}$ ).

The big bale size represents the normal size of bales on this production weighing from $689 \pm 18 \mathrm{~kg}$ for the lucerne and weighing from $877 \pm 10.93 \mathrm{~kg}$ for the maize. The bales were placed gently on their flat ends without stacking and stored outside for 120 days at ambient temperature. Ten big bales for each forage were made without any additives and ten with the addition of L. lactis and L. buchneri inoculant.

\section{Suspension preparation and application}

The bacterial suspension was sprayed during the bailing process with a commercial pump HP-20 (Junkkari Oy, Ylihärmä, Finland) mounted on a pick-up press for both lucerne and maize forage. Inoculant was dissolved in chlorine-free water

Table 1. Experimental design

\begin{tabular}{|c|c|c|c|c|}
\hline \multirow{2}{*}{$\begin{array}{l}\text { Forage } \\
\text { Groups }\end{array}$} & \multicolumn{2}{|c|}{ Lucerne } & \multicolumn{2}{|c|}{ Maize } \\
\hline & $\mathrm{CL}$ & $\mathrm{IL}$ & $\mathrm{CM}$ & IM \\
\hline $\begin{array}{l}\text { Application of additive, } \\
\text { cfu/g of fresh forage }\end{array}$ & 0 & $\begin{array}{l}150000 \text { Lactococcus lactis and } \\
\text { Lactobacillus buchneri (50:50) }\end{array}$ & & $\begin{array}{l}150000 \text { Lactococcus lactis and Lactobacillus } \\
\text { buchneri (50:50) }\end{array}$ \\
\hline Total replications & 10 & 10 & 10 & 10 \\
\hline Description & \multicolumn{2}{|c|}{$\begin{array}{l}5 \text { replications for determination of fermentation } \\
\text { parameters and microbiological composition, } \\
5 \text { replications for aerobic stability }\end{array}$} & \multicolumn{2}{|c|}{$\begin{array}{l}5 \text { replications for determination of fermentation parameters } \\
\text { and microbiological composition, } 5 \text { replications for aerobic } \\
\text { stability }\end{array}$} \\
\hline
\end{tabular}

\section{Ensiling procedure}

Lucerne (Medicago sativa) before the flowering stage of maturity was swathed on $11^{\text {th }}$ July 2016 with mover-conditioner Kvernelend 2828 M (Kverneland Group, Klepp Stasjon, Norway) and wilted up to $32.8 \%$ DM. Wilted lucerne was picked
( $2 \mathrm{~g}$ inoculant/ 41 water/ tonne of fresh forage) and applied at 41 suspension for 1 tonne of fresh forage targeting a dosage of $1.5 \times 10^{5} \mathrm{cfu} / \mathrm{g}$ for both lucerne and maize forage (IL and IM, respectively). The same volume (4 1/t) of chlorine-free water was used instead of the suspension in the control treat- 
ments for both lucerne and maize forage (CL and $\mathrm{CM}$, respectively). Samples of the water used for inoculation were collected and analysed immediately (within an hour) using ISO method 15214:1998 (ISO, 1998).

\section{Sampling}

Ten samples of wilted lucerne forage were taken directly from the windrows and ten samples of fresh maize forage were taken directly from the wagons during big bale silage making time and each forage were composited to five samples for the chemical composition, acidity $(\mathrm{pH})$ and buffer capacity analyses.

Randomly chosen five big bales from each forage and each treatment were sampled after 120 days of storage for chemical and microbial analyses. Eight core samples were taken with a steel corer from the centre of one side of each bale at levels of $0.3 \mathrm{~m}$ below the top and above the bottom, two outside and inside samples were taken at $0.2 \mathrm{~m}$ and $0.4 \mathrm{~m}$ depth from the side surfaces respectively. Core samples were composited within the bale. Samples of the silages were tested for $\mathrm{DM}, \mathrm{pH}$, crude protein, lactate, acetate, butyrate, propionate, ammonia-N, alcohols, yeasts and moulds and total lactic acid bacteria count. Other five bales from each forage and each treatment were uncovered on the same day for aerobic stability test (AST) in the field. Five samples ( $1000 \mathrm{~g}$ each) from the same five bales that were going for the aerobic stability in the field were taken for AST in the laboratory.

\section{Aerobic stability test (AST)}

The silage ASTs in the field and the laboratory were performed as described previously by Jatkauskas et al. (2018). After removing the plastic cover from five bales, each bale was fitted with two thermocouple wires. The wires were positioned $0.30 \mathrm{~m}$ under the bale surface to monitor changes in bale temperature over time. Bale temperature was taken every six hours with data logging and control system MS3+ (Comet System s.r.o., Rožnov pod Radhoštěm, Czech Republic) and evaluated for minimum, maximum and average temperature over a 39-day air exposure period. The ambient temperature was also recorded every six hours by two thermocouple wires distributed side by side of bales and protected against direct sunlight. The maximum temperature of the silage inside bales, a sum of ambient temperature, a sum of temperature of the silage in control bales and a sum of temperature of the silage in inoculated bales during exposure to air period were used to denote aerobic stability.
Maximum temperature and time to reach maximum temperature were also recorded. At the start (after removing plastic cover) and at the end of the AST, bales were rated visually for visible signs of mould growth and other signs of aerobic deterioration covering the entire surface of the bale. Any visible signs of surface deterioration were scored on a scale of 0.0 to 5.0 , where $0.0=$ ideal to $5.0=$ moulds and other aerobic deterioration signs. At the end of AST, big bales were individually weighed again for measuring weight losses during a 39-day aerobic exposure period and sampled to determine DM content, $\mathrm{pH}$ rise, and yeast and mould counts. For AST on the laboratory scale, a $1000 \pm 10 \mathrm{~g}$ sample from each big bale ( 5 big bale from each treatment) was loosely placed into a round polystyrene box and allowed to aerobically deteriorate at a constant ambient temperature $\left(\sim 20^{\circ} \mathrm{C}\right)$. The top and bottom of the boxes contained a $2 \mathrm{~cm}$-diameter hole to allow air to enter and carbon dioxide $\left(\mathrm{CO}_{2}\right)$ to leave. A transducer was placed in the centre of the silage mass through a hole in the cover of the box, which exposed the silage to air. The ambient temperature and the temperature of each silage were recorded every 6 hours by a screen recorder KD 7 (Lumel, Zielona Góra, Poland). The ambient temperature was measured by using an empty control box. The aerobic stability of silages was examined by calculating the differences between the silage temperature and ambient temperature adjusted for the base ambient temperature. The aerobic stability of the laboratory silages was defined as the number of hours the silage remained stable before rising more than a $3{ }^{\circ} \mathrm{C}$ above the ambient temperature. The AST in the laboratory was run in parallel with the field big bales.

At the end of the AST in the field ( $200 \mathrm{~g}$ each) core samples (5 replications from each forage and treatment) and in the laboratory one sample per mini silo were taken to evaluate the $\mathrm{pH}$ value and the population of yeast, mould and lactic acid bacteria (LAB).

\section{Analytical methods}

The samples were analysed for the DM content, nutrient content and fermentation parameters as well as $\mathrm{pH}$, silage acids (lactic, acetic, butyric and propionic acids) and alcohols as described previously by Jatkauskas et al. (2013). The content of DM of forage and silage were determined by drying samples at $60{ }^{\circ} \mathrm{C}$, equilibrated to room humidity overnight, milled through a $1-\mathrm{mm}$ sieve and further dried at $105^{\circ} \mathrm{C}$ to constant weight. Silage DM content was corrected for volatile alcohols and fatty acids during 
the oven drying. Dry matter corrected for volatiles (DMc) was calculated according to the following equation (all concentrations expressed as $\mathrm{g} / \mathrm{kg}$ ):

$\mathrm{DMc}=\mathrm{DM}+0.95 \mathrm{FA}+0.08 \mathrm{LA}+0.77 \mathrm{PD}+$

$$
1.00 \mathrm{OA}, \mathrm{g} / \mathrm{kg} \mathrm{FM} \text {, }
$$

where: FA - fatty acids (C2-C6), LA - lactic acid, $\mathrm{PD}$ - 1.2-propanediol, OA - other alcohols (C2-C4, including 2.3-butanediol) (Weissbach and Strubelt, 2008).

The total nitrogen was determined by Kjeldahl method (AOAC method 984.13; AOAC International, 2000). Crude protein (CP) content was calculated by multiplying the total nitrogen content by a factor of 6.25 . Water-soluble carbohydrates (WSC) were determined by using the anthrone reaction assay from the silage extracts obtained from steeping silage in water. Buffering capacity of the forage was determined according to Playne and McDonald, (1966), expressed as $\mathrm{mEq}$ of alkali required to change the $\mathrm{pH}$ from 4 to 6 per $1 \mathrm{~kg}$ of DM. Lactic acid, volatile fatty acid and alcohol concentrations were determined in silage extracts, prepared by adding $150 \mathrm{~g}$ of demineralized, deionized water to $30 \mathrm{~g}$ of silage for $16 \mathrm{~h}$ at $4{ }^{\circ} \mathrm{C}$ in a sealed container. This was followed by a preliminary filtering through $3-\mu \mathrm{m}$ filter paper. Deionized water $(3 \mathrm{ml})$ from an internal standard solution $(0.5 \mathrm{~g}$ 3-methyln-valeric acid in $1000 \mathrm{ml} 0.15 \mathrm{~mol} / \mathrm{l}$ oxalic acid) was added to $1 \mathrm{ml}$ of filtrate from the above, and the solution was filtered through a $0.45-\mu \mathrm{m}$ polyethersulfone membrane into a chromatographic sample vial for analysis. Gas-liquid chromatograph GC-2010 Shimadzu (Shimadzu Corp., Kyoto, Japan) with wide-bore capillary column (Stabilwax ${ }^{\circledR}$-DA $30 \mathrm{~m}$, $0.53 \mathrm{~mm}$ ID, $0.5 \mu \mathrm{m}$ ) (Restek Corp., Bellefonte, PA, USA) was used according to gas chromatography and biochemistry analyzer official methods (AOAC 963.15; AOAC International, 2000). The $\mathrm{pH}$ value was measured and recorded by using Thermo Orion Posi-pHloSymp-Hony electrode and Thermo Orion 410 meter (Thermo Fisher Scientific, Waltham, MA, USA).

Microbial composition was measured at National Food and Veterinary Risk Assessment Institute (Vilnius, Lithuania). The LAB, yeasts and moulds counts were determined by colony-count technique at $25^{\circ} \mathrm{C}$ using ISO method 15214:1998 (ISO, 1998) and 21527-1:2008 (ISO, 2008). Fermentability coefficient (FC) was calculated according to Weissbach (1996):

$$
\begin{gathered}
\mathrm{FC}=\mathrm{DM} \%+(8 \times(\mathrm{WSC}, \mathrm{DM} \%) / \\
(\mathrm{BC}, \mathrm{g} \text { lactate } / 100 \mathrm{~g} \mathrm{DM})),
\end{gathered}
$$

where: DM - dry matter, WSC - water soluble carbohydrates and $\mathrm{BC}$ - buffering capacity.

\section{Statistical analysis}

The statistical analysis of data was performed with the program package SPSS 20.0 (SPSS Inc., Chicago, IL, USA). The used measures (chemical and microbiological composition of lucerne and whole crop maize forage prior to ensiling; fermentation parameters of silages after 120 days of storage and microbiological composition and aerobic stability characteristic of silages) were arithmetic mean of one random variable $(\mathrm{M})$ and standard deviation (SD).

Aerobic stability data for each herbage type were estimated in the following two ways: (1) hours for a $3{ }^{\circ} \mathrm{C}$ increase in temperature (laboratory test) and (2) statistical analysis using a model as randomized complete block and temperature measurements data treated as repeated measurements (sets of data for every $6 \mathrm{~h}$ - field test).

In order to compare silage parameters between groups, a one-factor analysis of variance (ANOVA) was applied. The differences between the means were evaluated Fisher's LSD criterion. Student's t-test was used to find statistical differences between groups. Differences at the value of $P<0.05$ were considered significant.

\section{Results}

The chemical and microbiological composition of lucerne and whole crop maize forage before ensiling are summarized in Table 2. Fresh lucerne had $32.76 \%$ DM content, protein content was $22.02 \%$ of DM, while WSC was $5.01 \%$ of DM. Buffering capacity was $48.9 \mathrm{mEq} / 100 \mathrm{~g} \mathrm{DM}$. The $\mathrm{pH}$ of the fresh lucerne was 6.17. Based on these indicators, the calculated FC was 40.9. Fresh matter basis had

\begin{tabular}{|c|c|c|c|c|c|c|}
\hline \multirow{3}{*}{ Indices } & \multicolumn{6}{|c|}{ Fresh forage } \\
\hline & \multicolumn{3}{|c|}{ lucerne } & \multicolumn{3}{|c|}{ maize } \\
\hline & $n$ & mean & SD & $\mathrm{n}$ & mean & SD \\
\hline Dry matter (DM), g/kg & 5 & 327.6 & 4.74 & 5 & 336.9 & 5.51 \\
\hline Crude protein, g/kg DM & 5 & 220.2 & 8.53 & 5 & 98.4 & 5.27 \\
\hline Starch, g/kg DM & - & - & - & 5 & 371.8 & 1.92 \\
\hline WSC, g/kgDM & 5 & 50.1 & 2.11 & 5 & 74.7 & 4.54 \\
\hline Yeast, $\log _{10} \mathrm{cfu} / \mathrm{g}$ & 5 & 4.83 & 0.52 & 5 & 5.16 & 0.16 \\
\hline Moulds, $\log _{10} \mathrm{cfu} / \mathrm{g}$ & 5 & 4.65 & 0.33 & 5 & 4.89 & 0.25 \\
\hline $\mathrm{LAB}, \log _{10} \mathrm{cfu} / \mathrm{g}$ & 5 & 4.92 & 0.07 & 5 & 4.42 & 0.40 \\
\hline $\begin{array}{l}\text { Buffering capacity, } \\
\mathrm{mEq} / 100 \mathrm{~g} \mathrm{DM}\end{array}$ & 5 & 48.90 & 6.63 & 5 & 25.98 & 1.43 \\
\hline $\mathrm{pH}$ & 5 & 6.17 & 0.02 & 5 & 5.88 & 0.08 \\
\hline
\end{tabular}

Table 2. The chemical and microbiological composition of lucerne and whole crop maize forage prior to ensiling

LAB - lactic acid bacteria; SD - standard deviation; WSC - watersoluble carbohydrates 
Table 3. Microbiological composition and fermentation parameters of silages after 120 days of storage

\begin{tabular}{|c|c|c|c|c|}
\hline \multirow{3}{*}{ Variable } & \multicolumn{4}{|l|}{ Silages $^{1}$} \\
\hline & \multicolumn{2}{|l|}{ lucerne } & \multicolumn{2}{|l|}{ maize } \\
\hline & $\mathrm{CL}$ & IL & $\mathrm{CM}$ & $\mathrm{IM}$ \\
\hline $\begin{array}{l}\text { Dry matter (DM), g/kg } \\
\text { (corrected for volatiles) }\end{array}$ & $312.2 \pm 3.29$ & $321.9 \pm 1.72^{* *}$ & $315.6 \pm 2.71$ & $323.4 \pm 4.72^{* *}$ \\
\hline Yeast, $\log _{10} \mathrm{cfu} / \mathrm{g}$ & $2.88 \pm 0.12$ & $1.18 \pm 0.27^{\star *}$ & $4.55 \pm 0.48$ & $2.37 \pm 0.24^{* *}$ \\
\hline Mould, $\log _{10} \mathrm{cfu} / \mathrm{g}$ & $2.15 \pm 0.15$ & $1.42 \pm 0.16^{\star *}$ & $2.56 \pm 0.19$ & $1.22 \pm 0.21^{* *}$ \\
\hline $\mathrm{LAB}, \log _{10} \mathrm{cfu} / \mathrm{g}$ & $6.12 \pm 0.18$ & $7.44 \pm 0.31^{\star *}$ & $5.60 \pm 0.33$ & $7.27 \pm 0.40^{* *}$ \\
\hline $\mathrm{pH}$, after $120 \mathrm{~d}$ & $4.79 \pm 0.06$ & $4.45 \pm 0.05^{\star *}$ & $4.07 \pm 0.03$ & $3.91 \pm 0.01^{* *}$ \\
\hline Total acids, g/kg DM & $54.20 \pm 3.90$ & $91.8 \pm 5.93^{* *}$ & $34.39 \pm 2.92$ & $58.54 \pm 4.53^{* *}$ \\
\hline Lactic acid, g/kg DM & $32.00 \pm 3.87$ & $61.40 \pm 4.78^{\star *}$ & $22.92 \pm 2.01$ & $39.98 \pm 3.23^{* *}$ \\
\hline Acetic acid, g/kg DM & $15.80 \pm 1.30$ & $27.8 \pm 1.30^{* *}$ & $8.54 \pm 0.81$ & $17.47 \pm 1.19^{* *}$ \\
\hline Butyric acid, g/kg DM & $5.49 \pm 0.68$ & $1.50 \pm 0.43^{\star *}$ & $2.20 \pm 0.76$ & $0.37 \pm 0.06^{\star *}$ \\
\hline Propionic acid, g/kg DM & $0.67 \pm 0.21$ & $0.96 \pm 0.19$ & $0.56 \pm 0.09$ & $0.70 \pm 0.24$ \\
\hline Ethanol, g/kg DM & $8.00 \pm 1.00$ & $4.20 \pm 0.84^{* *}$ & $16.86 \pm 2.87$ & $11.21 \pm 0.87^{*}$ \\
\hline
\end{tabular}

1 silages: $\mathrm{CL}$ - control lucerne, IL - inoculated lucerne, $\mathrm{CM}$ - control maize, IM - inoculated maize; LAB - lactic acid bacteria; results presented as mean \pm standard deviation (SD); ${ }^{*}$ and ${ }^{* *}$ indicate statistically significant difference vs adequate control at level 0.05 and 0.01 , respectively

$4.83 \log _{10} \mathrm{cfu} / \mathrm{g}$ yeast and $4.65 \log _{10} \mathrm{cfu} / \mathrm{g}$ moulds. Epiphytic LAB reached $4.92 \log _{10} \mathrm{cfu} / \mathrm{g}$. Fresh whole crop maize had 33.69\% DM. The $\mathrm{pH}$ value reached 5.88. WSC concentration was $7.47 \%$ of DM. BC was $25.98 \mathrm{mEq} / 100 \mathrm{~g}$ DM. Based on these indicators, the calculated FC was 56.7. Fresh matter basis had $5.16 \log _{10} \mathrm{cfu} / \mathrm{g}$ yeast and $4.89 \log _{10} \mathrm{cfu} / \mathrm{g}$ moulds while epiphytic LAB reached $4.42 \log _{10} \mathrm{cfu} / \mathrm{g}$.

The results of fermentation parameters and microbiological analyses of the silages after 120 days of ensiling are summarized in Table 3. IL and IM silages had greater DM content by $3.0 \%(P<0.01)$ and by $2.5 \%(P<0.01)$, respectively, in comparison to control silages. IL silage had $69.4 \%(P<0.01)$ greater amount of organic acids, 91.9\% $(P<0.01)$ more lactic acid and 75.9\% $(P<0.01)$ more acetic acid in comparison to CL. CL silage had 3.7 times more $(P<0.01)$ butyric acid and 1.9 times more $(P<0.01)$ of ethanol than IL. The $\mathrm{pH}$ value of the CL group was by 0.34 units greater $(P<0.01)$ than the IL group silages. IM silage had by 1.7 times greater total amount of organic acids $(P<0.01)$, more lactic acid by $74.4 \%(P<0.01)$ and by $104.6 \%$ $(P<0.01)$ greater amount of acetic acid in comparison to the CM silage. The IM silage had a lesser amount of undesirable fermentation products: 5.9 times less butyric acid $(P<0.01), 1.5$ times less ethanol $(P<0.05)$ and the $\mathrm{pH}$ value was by 0.3 unit lesser $(P<0.01)$ than the CM silage. It has been determined that inoculation positively and substantially affected the silage microbial population. The IL silage had less yeast count $(P<0.01)$ and less mould count $(P<0.01)$, while LAB count was greater $(P<0.01)$ in comparison to the CL silage. The IM silage had less yeast count $(P<0.01)$ and less mould count
$(P<0.01)$ than the CM silage, and the number of LAB was greater $(P<0.01)$.

The results of AST field measurements of the silages are presented in Table 4. CL silage after AST had more yeast $(P<0.01)$ and more mould $(P<0.01)$, also LAB count was lesser $(P<0.01)$ in it than in the IL silage. The IM silage showed lesser yeast and mould count $(P<0.01$ for both) in comparison to the CM silage. The number of LAB in IM silage, after AST in field scale, was greater $(P<0.01)$ than in the CM silage.

Inoculant treatment had a great impact on the visible mould growth on the surface area of big bales after 120 days of storage period and after big bales aerobic exposure during AST (Table 4). After 120-day storage period, fungal growth was visibly present on the surface of three CL big bales with $1-5$ visible colony and on the surface of two CM big bales with 1-3 visible colony, when neither IL or IM bales had visible signs of the mould. Therefore, $\mathrm{CL}$ and $\mathrm{CM}$ big bales were scored as 0.6 and 0.4 respectively, when IL and IM big bales were scored as 0 . At the end of the AST, it was detected that the number of visible colonies on surface of CL bales were: with 3 visible colonies - 2 bales, with 2 visible colonies -2 bales and with 1 visible colony -1 bale, and CM bales were: with 4 visible colonies -2 bales, with 3 visible colonies -2 bales and with 1 visible colony - 1 bale. Therefore, CL and CM big bales were scored as 2.2, and IL and IM bales were scored as 0.6 .

It was observed that the $\mathrm{pH}$ value of the IL silage was more stable during aerobic exposure time and was by 2.2 units lesser $(P<0.01)$ than the $\mathrm{CL}$ silage (Table 4). Herewith, the $\mathrm{pH}$ value in IM silage 
Table 4. Microbiological composition and aerobic stability characteristics of silages after aerobic stability test (AST) in field scale

\begin{tabular}{|c|c|c|c|c|}
\hline \multirow{3}{*}{ Indices } & \multicolumn{4}{|l|}{ Silages $^{1}$} \\
\hline & \multicolumn{2}{|l|}{ lucerne } & \multicolumn{2}{|l|}{ maize } \\
\hline & $\mathrm{CL}$ & IL & $\mathrm{CM}$ & IM \\
\hline Yeast after AST, $\log _{10} \mathrm{cfu} / \mathrm{g}$ & $3.59 \pm 0.31$ & $2.68 \pm 0.26^{* *}$ & $8.09 \pm 0.30$ & $3.76 \pm 0.19^{* *}$ \\
\hline Mould after AST, $\log _{10} \mathrm{cfu} / \mathrm{g}$ & $8.59 \pm 0.87$ & $6.08 \pm 0.68^{* *}$ & $6.11 \pm 0.72$ & $3.68 \pm 0.15^{\star *}$ \\
\hline LAB after AST, $\log _{10} \mathrm{cfu} / \mathrm{g}$ & $5.61 \pm 0.18$ & $6.81 \pm 0.15^{\star *}$ & $5.35 \pm 0.34$ & $7.16 \pm 0.47^{* *}$ \\
\hline Visible moulds score before AST & $0.60 \pm 0.55$ & $0.00 \pm 0.00^{*}$ & $0.40 \pm 0.55$ & $0.00 \pm 0.00$ \\
\hline Visible moulds score after AST & $2.20 \pm 0.84$ & $0.60 \pm 0.89^{*}$ & $2.20 \pm 0.84$ & $0.60 \pm 0.89^{*}$ \\
\hline $\mathrm{pH}$ after AST & $7.51 \pm 1.01$ & $5.31 \pm 0.40^{\star *}$ & $4.93 \pm 0.08$ & $4.31 \pm 0.04^{* *}$ \\
\hline Max sample temperature during $\mathrm{AST},{ }^{\circ} \mathrm{C}$ & $59.20 \pm 7.08$ & $23.20 \pm 15.89^{* *}$ & $33.40 \pm 8.50$ & $13.20 \pm 3.83^{*}$ \\
\hline Aerobic stability, h & $144.0 \pm 44.2$ & $714.0 \pm 208.7$ & $318.0 \pm 94.4$ & $642.0 \pm 187.9^{\star \star}$ \\
\hline
\end{tabular}

${ }^{1}$ silages: CL - control lucerne; IL - inoculated lucerne; CM - control maize; IM - inoculated maize; LAB - lactic acid bacteria; results presented as mean \pm standard deviation (SD); ${ }^{*}$ and ** indicate statistically significant difference vs adequate control at level 0.05 and 0.01 , respectively

Table 5. Microbiological composition and aerobic stability characteristics of silages after aerobic stability test (AST) in laboratory

\begin{tabular}{|c|c|c|c|c|}
\hline \multirow{3}{*}{ Indices } & \multicolumn{4}{|c|}{ Silages $^{1}$} \\
\hline & \multicolumn{2}{|l|}{ lucerne } & \multicolumn{2}{|l|}{ maize } \\
\hline & $\mathrm{CL}$ & IL & $\mathrm{CM}$ & $\mathrm{IM}$ \\
\hline Yeast after AST, $\log _{10}$ cfu/g & $3.72 \pm 0.68$ & $2.42 \pm 0.28^{*}$ & $8.99 \pm 0.49$ & $4.86 \pm 0.37^{*}$ \\
\hline Mould after AST, $\log _{10} \mathrm{cfu} / \mathrm{g}$ & $8.26 \pm 0.47$ & $6.57 \pm 0.38^{*}$ & $7.90 \pm 0.29$ & $4.63 \pm 0.29^{*}$ \\
\hline LAB after AST, $\log _{10} \mathrm{cfu} / \mathrm{g}$ & $5.94 \pm 0.45$ & $7.00 \pm 0.41^{*}$ & $5.40 \pm 0.43$ & $7.50 \pm 0.55^{\star}$ \\
\hline $\mathrm{pH}$ after AST & $8.68 \pm 0.16$ & $6.77 \pm 0.82^{*}$ & $6.94 \pm 0.05$ & $4.76 \pm 0.09^{*}$ \\
\hline Max sample temperature during $\mathrm{AST},{ }^{\circ} \mathrm{C}$ & $27.20 \pm 1.05$ & $25.30 \pm 0.85$ & $34.40 \pm 1.40$ & $26.90 \pm 0.26^{\star}$ \\
\hline Aerobic stability, $\mathrm{h}$ & $186.0 \pm 56.3$ & $288.0 \pm 85.7$ & $60.0 \pm 19.9$ & $282.0 \pm 84.0^{*}$ \\
\hline
\end{tabular}

${ }_{1}^{1}$ silages: $\mathrm{CL}$ - control lucerne, IL - inoculated lucerne, CM - control maize, IM - inoculated maize; LAB - lactic acid bacteria; results presented as mean \pm standard deviation (SD); ${ }^{*}$ - indicates statistically significant difference vs control at level 0.01

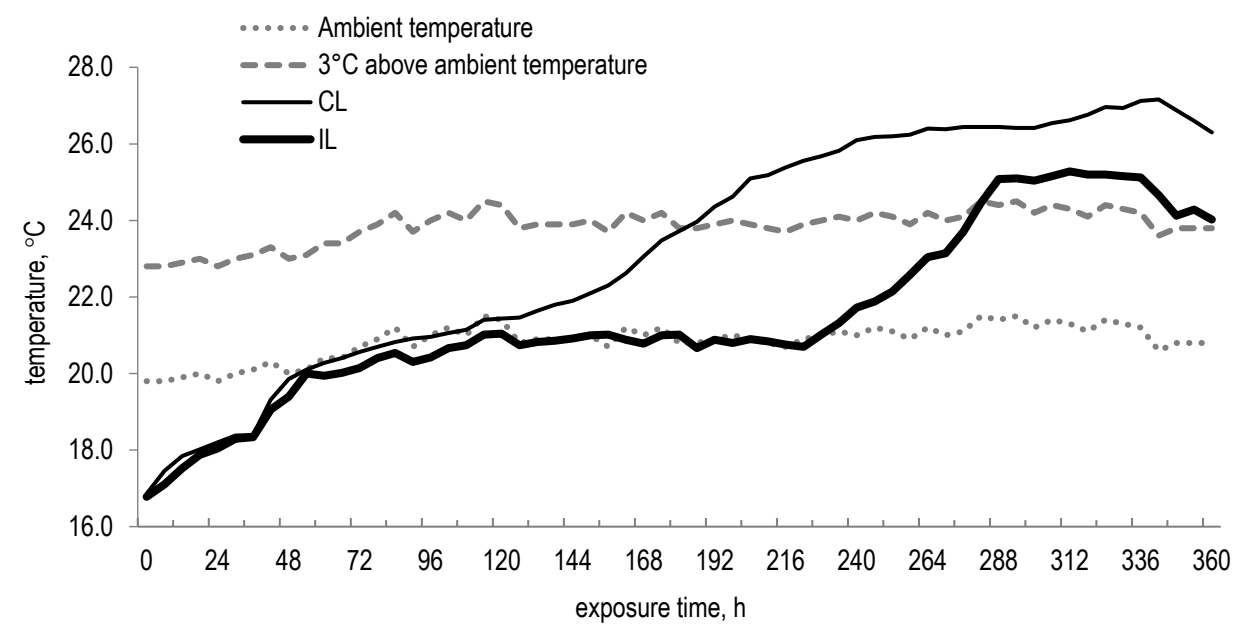

Figure 1. Temperature change dynamics during aerobic exposure period on the laboratory scale (lucerne silage: control and inoculated with a blend of lactic acid bacteria containing Lactococcus lactis and Lactobacillus buchneri, CL and IL, respectively)

was by 0.62 units lower than in CM silage. The maximum sample temperature in the CL silage was $36.0{ }^{\circ} \mathrm{C}$ or 2.6 times higher $(P<0.01)$ than in the IL silage. Maximum temperature in the IM silage was by $20.17^{\circ} \mathrm{C}$ lesser $(P<0.05)$ in comparison to $\mathrm{CM}$ silage. The aerobic stability of the IL silage was by 23.75 days longer than of the CL silage. The IM silage was aerobically stable for 26.75 days, when CM silage was aerobically stable for 13.25 days.
Therefore, aerobic stability of the IM silage was by 13.5 days longer than of $\mathrm{CM}$ silage $(P<0.01)$.

After AST in laboratory, the IL silage had lesser yeast count $(P<0.01)$, less mould count $(P<0.01)$ and greater LAB count $(P<0.01)$ than $C L$ silage (Table 5). The IM silage had lesser yeast count $(P<0.01)$ and lesser mould count and greater LAB count $(P<0.01)$, than the CM silage. The $\mathrm{pH}$ of the CL silage was by 1.91 units $(P<0.01)$ greater 


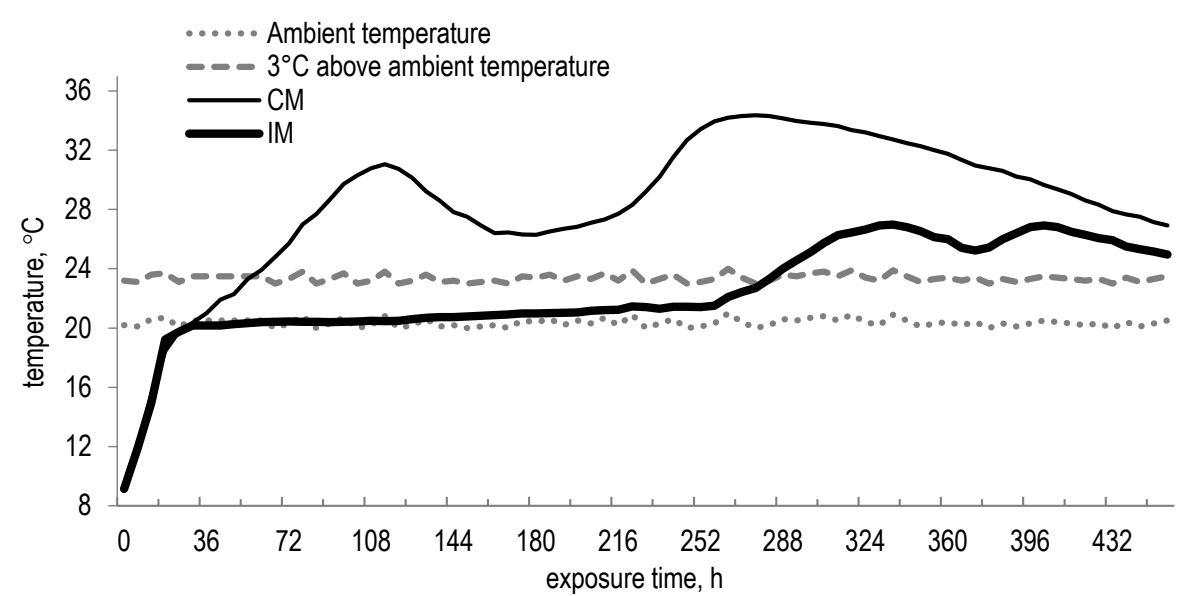

Figure 2. Temperature change dynamics during aerobic exposure period on the laboratory scale (maize silage: control and inoculated with a blend of lactic acid bacteria containing Lactococcus lactis and Lactobacillus buchneri, CM and IM, respectively)

than of the IL silage. In the CM silage, the $\mathrm{pH}$ value reached 6.94 units and was by 2.18 units greater $(P<0.01)$ than in the IM silage. The CL silage remained aerobically stable for 7.75 days, while the IL silage was aerobically stable for 12 days or by 4.25 days longer than the CL silage. However, statistically significant difference $(P<0.05)$ was recorded from 186 to $270 \mathrm{~h}$ of the test (Figure 1). The bacterial silage inoculant had a positive effect on aerobic stability of maize silage in laboratory scale. The maximum sample temperature during the AST in CM silage was by $7.38{ }^{\circ} \mathrm{C}$ higher $(P<0.01)$ than in the IM silage. Temperature change dynamics during AST test under laboratory conditions is shown in Figure 2. The $\mathrm{CM}$ silage reached a temperature of $+3{ }^{\circ} \mathrm{C}$ above the ambient temperature after 2.5 days and IM silage after 11.75 days. Therefore, the aerobic stability of IM silage was by 9.25 days longer $(P<0.01)$ when compared to the CM silage.

\section{Discussion}

Recently, dual-purpose inoculants containing homo-fermentative and hetero-fermentative bacteria have been developed to improve the speed of fermentation and the aerobic stability (Queiroz et al., 2012; Li et al., 2016). In this study inoculated silages had significantly greater levels of lactic acid and reduced $\mathrm{pH}$ value in both lucerne and maize silages. The decrease in the $\mathrm{pH}$ of the inoculated silage during fermentation may be associated with an increase in lactic acid concentration (Tyrolová et al., 2017). This study demonstrated that the bacterial additive increased amount of acetic acid. Acetic acid has antifungal properties, which reduces the failure of the silage under aerobic conditions and the growth of yeasts and moulds (Đorđević et al., 2017). In our study yeast counts were numerically greater in untreated silages and can be related with lesser acetic acid concentration. We also observed that concentration of ethanol was lesser in treated silages. Ethanol is the most commonly found alcohol in silage, which can be produced by various microorganisms such as Enterobacteriaceae or yeast. High levels of ethanol ( $>3-4 \%$ ) are often associated with high levels of yeast (Kung et al., 2018). Such silage is aerobically unstable when exposed to air, because yeast destroys lactic acid (Kung et al., 2018). Our findings indicate that addition of LAB inoculation caused lesser yeast and moulds count in both lucerne and maize silages. Previous studies have reported that combining specific strains of L. buchneri and L. lactis as a silage inoculant can efficiently control yeast and moulds growth in grass and maize silages (Copani et al., 2018; Jatkauskas et al., 2018).

In this study we have shown that inoculated silages had significantly better aerobic stability than the control ones. These results are directly related to the inhibition of growth of yeast and moulds. Johnson (2017) demonstrated that treating maize with silage inoculant containing L. buchneri and L. lactis had no effect on the aerobic stability of maize silage. Conversely, we have observed that silage inoculant had a positive effect on aerobic stability by delaying aerobic deterioration time. The present results are in agreement with several previous studies, where inoculation with $L$. buchneri and L. lactis improved aerobic stability in various silages (Witt et al., 2015; Copani et al., 2017; Gallo et al., 2018). 
The results of the present study confirm that applying bacterial inoculant containing $L$. buchneri and L. lactis can efficiently control yeast and moulds growth and improve aerobic stability of maize and lucerne ensiled in big bales.

\section{Conclusions}

Application of viable homo and hetero lactic acid bacteria (LAB) Lactobacillus buchneri combined with Lactococcus lactis improved lucerne and whole crop maize silage quality. Such combination was effective in changing the fermentation profile resulting in the more heterolactic fermentation and in the decreased concentration of butyric acid and alcohols in both lucerne and whole crop maize silages. Application of the mixed LAB improved also aerobic stability and gave lower yeast and mould count in both examined silages. Decreased visible fungi growth on the surface of the inoculated silages at opening and after aerobic exposure period correlated with an improved aerobic stability.

\section{References}

AOAC International, 2000. Official Methods of Analysis of AOAC International. $17^{\text {th }}$ Edition. Gaithersburg, MD (USA)

Auerbach H., Nadeau E., 2018. Biological and chemical additives maintain nutritive value of grass silage. In: K. Gerlach, K.H. Südekum (Editors). Proceedings of the XVIII International Silage Conference. Bonn (Germany), pp. 220-221

Borreani G., Tabacco E., Schmidt R.J., Holmes B.J., Muck R.E., 2018. Factors affecting dry matter and quality losses in silages. J. Dairy Sci. 101, 3952-3979, https://doi.org/10.3168/ jds.2017-13837

Copani G., Milora N., Bryan K.A., Nielsen N. G., Witt K. L., 2018. Fermentation and aerobic stability of grass and grass-legume silages ensiled. In: K. Gerlach, K.H. Südekum (Editors). Proceedings of the XVIII International Silage Conference. Bonn (Germany). pp. 286-287

Copani G., Nielsen N.G., Bryan K.A., Vrotniakiene V., Jatkauskas J., Witt K.L., 2017. Effects of a dual strain inoculant on alfalfa silage fermentation and aerobic stability through 32 days of ensiling. In: L.G. Nussio, D.O. De Sousa, V.C. Gritti, G.G. De Souza Salvati, W.P. Dos Santos, P.A.R. Salvo (Editors). Proceedings of the $V$ International Symposium on Forage Quality and Conservation. Piracicaba, Sao Paulo (Brazil)

DLG, 2000. DLG guidelines for the testing of silage additives for compliance with DLG quality label requirements. DLG Verlags-GmbH. Frankfurt a.M. (Germany)

Đorđević S., Mandić V., Stanojević D., Jovanović-Ljesković N., 2017. Effects of Lactobacillus plantarum inoculants on maize silage quality. Biotechnol. Anim. Husbandry 33, 115-125, https://doi. org/10.2298/bah1701115d

EFSA, 2006. Opinion of the Panel on additives and products or substances used in animal feed (FEEDAP) for the establishment of guidelines on the assessment of safety and efficacy of silage additives, on a request from the Commission under Article 7(5) of Regulation (EC) No 1831/2003. EFSA-Q-2004-088. EFSA J. 374, 1-115
Gallo A., Bernardes T.F., Copani G., Fortunati P., Giuberti G., Bruschi S., Bryan K.A., Nielsen N.G., Witt K.L., Masoero F., 2018. Effect of inoculation with Lactobacillus buchneri LB1819 and Lactococcus lactis O224 on fermentation and mycotoxin production in maize silage compacted at different densities. Anim. Feed Sci. Technol. 246, 36-45, https://doi. org/10.1016/j.anifeedsci.2018.09.009

ISO, 1998. ISO method 15214:1998. Microbiology of food and animal feeding stuffs - Horizontal method for the enumeration of mesophilic lactic acid bacteria - Colony-count technique at 30 degrees $C$

ISO, 2008. ISO method 21527-1:2008. Microbiology of food and animal feeding stuffs - Horizontal method for the enumeration of yeasts and moulds - Part 1: Colony count technique in products with water activity greater than 0.95

Jatkauskas J., Vrotniakiene V., Ohlsson C., Lund B., 2013. The effects of three silage inoculants on aerobic stability in grass, clover-grass, lucerne and maize silages. Agric. Food Sci. 22, 137-144, https://doi.org/10.23986/afsci.6698

Jatkauskas J., Vrotniakiene V., Stoškus R., 2018. Variations in fermentation, bacterial population and aerobic stability in maize silage. Zemdirbyste-Agric. 105, 377-382, https://doi. org/10.13080/z-a.2018.105.048

Johnson J.R. (Editor), 2017. Techniques to increase silage stability and starch availability and the effects of heat stress abatement systems on reducing heat load in dairy cattle. $\mathrm{PhD}$ Dissertation. Kansas State University (USA)

Juškienė V., Jatkauskas J., Bliznikas S., Švirmickas G., Uchockis V., Vrotniakienè V., 2014. Quality assessment of feedingstuffs in livestock productivity controls in dairy cattle. Final Report (in Lithuanian: Pašaru kokybès jvertinimas pieniniu galviju bandose, kuriose vykdoma produktyvumo kontrolè. Galutinè ataskaita). Lithuanian University of Health Sciences, Baisogala (Lithuania), pp. 61

Kung L., Shaver R.D., Grant R.J., Schmidt R.J., 2018. Silage review: Interpretation of chemical, microbial and organoleptic components of silages. J. Dairy Sci. 101, 4020-4033, https:// doi.org/10.3168/jds.2017-13909

Li X., Xu W., Yang J., Zhao H., Pan C., Ding X., Zhang Y., 2016. Effects of applying lactic acid bacteria to the fermentation on a mixture of corn steep liquor and air-dried rice straw. Anim. Nutr. 2, 229-233, https://doi.org/10.1016/j.aninu.2016.04.003

Mogodiniyai Kasmaei K., Rustas B.-O., Spörndly R., Udén P., 2013. Prediction models of silage fermentation products on crop composition under strict anaerobic conditions: A metaanalysis. J. Dairy Sci. 96, 6644-6649, https://doi.org/10.3168/ jds.2013-6858

Ogunade I.M., Arriola K.G., Jiang Y., Driver J.P., Staples C.R., Adesogan A.T., 2016. Effects of 3 sequestering agents on milk aflatoxin $M_{1}$ concentration and the performance and immune status of dairy cows fed diets artificially contaminated with aflatoxin B. J. Dairy Sci. 99, 6263-6273, https://doi. org/10.3168/jds.2016-10905

Playne M.J., McDonald P., 1966. The buffering constituents of herbage and of silage. J. Sci. Food Agric. 17, 264-268, https://doi. org/10.1002/jsfa.2740170609

Queiroz O.C.M., Adesogan A.T., Arriola K.G., Queiroz M.F.S., 2012. Effect of a dual-purpose inoculant on the quality and nutrient losses from maize silage produced in farm-scale silos. J. Dairy Sci. 95, 3354-3362, https://doi.org/10.3168/jds.2011-5207

Queiroz O.C.M., Ogunade I.M., Weinberg Z., Adesogan A.T., 2018. Silage review: Foodborne pathogens in silage and their mitigation by silage additives. J. Dairy Sci. 101, 4132-4142, https://doi.org/10.3168/jds.2017-13901 
Tyrolová Y., Bartoň L., Loučka R., 2017. Effects of biological and chemical additives on fermentation progress in maize silage. Czech J. Anim. Sci. 62, 306-312, https://doi. org/10.17221/67/2016-CJAS

Weissbach F., 1996. New developments in crop conservation. In: Proceedings of the $11^{\text {th }}$ International Silage Conference. Aberystwyth, Wales (UK), pp. 11-25

Weissbach F., Strubelt C., 2008. Correcting the dry matter content of maize silages as a substrate for biogas production. Landtechnik 63, 210-211
Witt K.L., Jatkauskas J., Vrotniakiene V., Voss M.T., 2015. Effects of a novel dual purpose silage additive on aerobic stability and fermentation characteristics of whole crop maize silage after a short time of ensiling, In: L.G. Nussio, D.O. De Sousa, V.C. Gritti, G.G. De Souza Salvati, W.P. Dos Santos, P.A.R. Salvo (Editors). Proceedings of the XVII International Silage Conference. Piracicaba, Sao Paulo (Brazil), pp. 82-83 